\title{
PARTIAL PURIFICATION AND CHARACTERIZATION OF EXOPOLYGALACTURONASE II AND III OF PENICILLIUM FREQUENTANS
}

\author{
Renata I. Barense; Maria Angélica dos S.C. Chellegatti; Maria José V. Fonseca; Suraia Said* \\ Departamento de Ciências Farmacêuticas, Faculdade de Ciências Farmacêuticas de Ribeirão Preto - Universidade de São Paulo, \\ Ribeirão Preto, SP, Brasil
}

Submitted: November 08, 2000; Returned to authors for corrections: August 03, 2001; Approved: December 14, 2001

\begin{abstract}
Previous studies from our laboratory have demonstrated that the fungus Penicillium frequentans produces high levels of polygalacturonase and pectinesterase. Endopolygalacturonase I (Endo-PG I) and Exopolygalacturonase I (Exo-PG I) were previously purified and characterized. In the present study two extracellular polygalacturonases were separated, partially purified and biochemically characterized. Both were characterized as exopolygalacturonases so they were named exopolygalacturonase II (Exo-PG II) and exopolygalacturonase III (Exo-PG III) which had a molecular mass of $63 \mathrm{kDa}$ (Exo-PG II) and $79 \mathrm{kDa}$ (Exo-PG III). The $\mathrm{K}_{\mathrm{m}}$ values were 1.6 and $0.059 \mathrm{~g} / \mathrm{L}$ and the $\mathrm{V}_{\max }$ values were 2571 and $185 \mathrm{U} / \mathrm{mg}$, respectively. The optimum temperature was $50^{\circ} \mathrm{C}$ for both enzymes, while the optimum pH was 5.0 for Exo-PG II and 5.8 for Exo-PG III.
\end{abstract}

Key words: Exopolygalacturonase, pectinase, polygalacturonase, Penicillium frequentans.

\section{INTRODUCTION}

Pectinolytic enzymes are used mainly in the food industry, particularly for fruit juice clarification and for the isolation of essential oils and pigments from citrus. They are also used in the textile industry to release cellulose fibers from fibrous stalks $(1,5,19)$. Bacteria, fungi and yeast synthesize and secrete pectinases (19). In addition to their industrial importance, pectinases are of interest because they participate in the infection process together with other plant cell wall-degrading enzymes, thus facilitating the installation of pathogens in plants (18).

Previous studies have shown that Penicillium frequentans produces high levels of extracellular pectinases when cultured in liquid medium supplemented with citric pectin (20). The pectinolytic complex secreted by $P$. frequentans was initially separated in 5 distinct fractions (22). It was after detected that the fungus synthesized 13 pectinases, being 7 polygalacturonases and 2 pectinesterases secreted while 4 polygalacturonases were maintained inside the cell (10). Two extracellular polygalacturonases, pool I (endo-
PG I) and pool II (exo-PG I), were separated and biochemically characterized (4; Chellegatti et al., personal communication).

In the present study the pools III and IV which are part of extracellular polygalacturonase complex produced by $P$. frequentans were separated and biochemically characterized.

\section{MATERIALS AND METHODS}

\section{Microorganism and maintenance}

P. frequentans was isolated from soil (20) and deposited in the collection of Fundação Tropical de Pesquisa e Tecnologia André Tosello in Campinas under number FTPT 2037. The fungus was maintained by weekly transfers on tomato medium slants (8) and incubated at $30^{\circ} \mathrm{C}$ for 7 days.

\section{Enzyme production}

The culture medium described by Manachini et al. (12) and adapted according to Siéssere et al. (22) was inoculated with $5.10^{6}$ spores. $\mathrm{mL}^{-1}$ and incubated with agitation $(140 \mathrm{rev} / \mathrm{min})$ at $30^{\circ} \mathrm{C}$ for $24 \mathrm{~h}$. The mycelium was separated from the culture fluid

\footnotetext{
* Corresponding author: Mailing Address: Departamento de Ciências Farmacêuticas - Faculdade de Ciências Farmacêuticas de Ribeirão Preto - USP. Av. do Café, s/n - Bairro Monte Alegre - 14040.903, Ribeirão Preto - São Paulo - Brasil. Fax (+5516) 6331941. Tel.: (+5516) 6024224. E-mail: susaid@fcfrp.usp.br
} 
by filtration and the broth was dialyzed against $25 \mathrm{mM}$ sodium acetate buffer, $\mathrm{pH} 5.0$, containing 1 mM EDTA (buffer A). The dialyzed broth was used for the enzyme assays, or concentrated with crystalline sucrose (6) and dialyzed once against buffer A.

\section{Enzyme assays}

Polygalacturonase activity was assayed by the liberation of reducing sugar and by the decrease in viscosity of sodium polypectate solution. Reducing sugars were quantified by the dinitrosalicylic acid method (14). The enzymatic reaction was performed according to Siéssere et al. (22) and one activity was defined as the amount of enzyme which released $1 \mu \mathrm{mol}$ of reducing sugar groups per minute at $50^{\circ} \mathrm{C}$ and $\mathrm{pH} 5.0$, using Dgalacturonic acid as standard. Viscosity-diminishing activity was determined by measuring the decrease in relative viscosity (13) and according to Siéssere et al. (22). One relative viscosimetric unit was defined as the amount of enzyme which reduced the initial viscosity of the substrate solution by $50 \%$ in 1 minute of reaction at $50^{\circ} \mathrm{C}$ and $\mathrm{pH}$ 5.0. Pectinesterase activity was assayed according to Nasuno and Star (15). One unit of activity was the amount of enzyme which released 1 microequivalent of carboxyl groups per hour at $50^{\circ} \mathrm{C}$ and $\mathrm{pH} 6.5$ (22). Protein was determined by the method of Bensadoun and Weinstein (3) using albumin (Sigma) as standard.

\section{Separation of pectic enzymes}

The enzyme activities in dialyzed broth were separated by ion exchange chromatography. Samples ( 30 or $40 \mathrm{~mL}$ ) of broths were applied to a DEAE-Sephacel column $(1.8 \times 60.0 \mathrm{~cm})$ preequilibrated with $25 \mathrm{mM}$ Tris-acetate buffer, $\mathrm{pH} 6.5$, containing $1 \mathrm{mM}$ EDTA (buffer B). Proteins that was not bound to the resin were eluted with the same buffer. Bound proteins were eluted by stepwise increases in $\mathrm{NaCl}$ concentration in buffer B $(20$ and $300 \mathrm{mM})$ at flow rate of $0.71 \mathrm{~mL} \cdot \mathrm{min}^{-1}$ and $5 \mathrm{~mL}$ fractions were collected. The PIII and PIV fractions obtained with the DEAE-Sephacel column were rechromatographed on a new DEAE-Sephacel column $(1.6 \mathrm{x}$ $26.5 \mathrm{~cm}$ ) preequilibrated with buffer B and eluted with $50 \mathrm{mM}$ $\mathrm{NaCl}$. The flow rate of the mobile phase was $0.67 \mathrm{~mL} \cdot \mathrm{min}^{-1}$ and 5 $\mathrm{mL}$ fractions were collected.

\section{Determination of enzymes properties}

According to Rombouts and Pilnik (19), it is possible to determine whether a polygalacturonase acts on the substrate by attacking it by its ends or randomly within the chain by comparing the viscosimetric and reducing sugar-releasing activities of the enzyme in a $2.0 \%$ sodium polypectate $(\mathrm{NaPP})$ solution. The results are expressed as percentage of the loss of initial viscosity of the NaPP solution versus percentage of hydrolyzed glycoside bonds. The degradation products were confirmed by thin-layer chromatography (5). To determine the molecular mass of Exo-PG II and III, fractions of PIII and IV were collected from the DEAESephacel column dialyzed against buffer A and applied to a BioGel
P100 column $(1.8 \times 55.5 \mathrm{~cm})$ preequilibrated with the same buffer containing $100 \mathrm{mM} \mathrm{NaCl}$. The following molecular mass standards were used: $\beta$-amylase $(200,000)$, alcohol dehydrogenase $(150,000)$, bovine serum albumin $(66,000)$, carbon anhydrase $(20,000)$ and cytochrome C $(12,400)$. Optimum $\mathrm{pH}$ of Exo-PG II and III were determined in reactions carried out at $\mathrm{pH}$ values ranging from 1.2 to 8.0 using $25 \mathrm{mM}$ disodium phosphate-citric acid buffer and from 7.8 to 9.0 using $25 \mathrm{mM}$ Tris-HCl buffer. The reducing sugarreleasing activity was determined at $50^{\circ} \mathrm{C}$. The optimum temperature of each one was determined by evaluating the reducing sugar-releasing activity at temperatures ranging from $20^{\circ}$ to $75^{\circ} \mathrm{C}$ at $5^{\circ} \mathrm{C}$ intervals. The Michaelis constants of the ExoPG II and III were determined at various concentrations of sodium polipectate $(\mathrm{NaPP})$ and the data were plotted according to the Lineweaver-Burk plot.

\section{RESULTS AND DISCUSSION}

In previous studies from our laboratory the chromatographic profile of extracellular pectinases produced by Penicillium frequentans and separated on a DEAE-Sephacel column (1.6 x $25 \mathrm{~cm}$ ) presented 5 fractions with pectinolytic activity which were designated PI, PII, PIII, PIV and PV, but PII was not completely separated from the others (22). Using the same resin on a larger column $(1.8 \times 60 \mathrm{~cm})$ equilibrated with buffer B, PII could be completely separated from the other fractions, for a total of 6 fractions with pectinolytic activity (Chellegatti et al., personal communication). Of these fractions, PI was characterized as endo-PG I, with a $\mathrm{K}_{\mathrm{m}}$ of $2.7 \mathrm{~g} . \mathrm{L}^{-1}$ and $\mathrm{V}_{\max }$ of 488.28 U.mg-1 (4), PII as exo-PG I, $\mathrm{K}_{\mathrm{m}} 0.68 \mathrm{~g} . \mathrm{L}^{-1}$ and $\mathrm{V}_{\max } 596.8$ ${\mathrm{U} . \mathrm{mg}^{-1}}$ (Chellegatti et al., personal communication), PIII and PIV, which were the subject of the present study, and responsible for 47.6 and $44.4 \%$ respectively of total extracellular exopolygalacturonase activity were rechromatographed, reaching $49.17 \%$ (PIII) and $42.30 \%$ (PIV) purification in relation to the first DEAE-Sephacel column (Fig. 1).

While PIV presented only polygalacturonase activities, PIII showed also pectinesterase activity which even after several separation attempts could not be dissociated from the polygalacturonase activities, suggesting a complex of these two pectinolytic activities in this pool. The assays used to characterize the exo- or endo-nature of PIII and PIV polygalacturonases on the sodium polypectate substrate (NaPP) revealed that after $1 \mathrm{~h}$ of incubation with this substrate PIII and PIV reduced the initial viscosity of the solution by 7.43 and $7.81 \%$, respectively, whereas the percentage of degraded glycoside bonds during the same period was 15.94 and 15.0\%, respectively (Fig. 2). According to Rombouts and Pilnik (19), an enzyme presents an endo character when the initial viscosity is reduced by half and less than $15 \%$ of the glycoside bonds of the substrate are hydrolyzed; therefore the PIII and PIV enzymes are exopolygalacturonases. These results were confirmed by thin-layer chromatography of the 

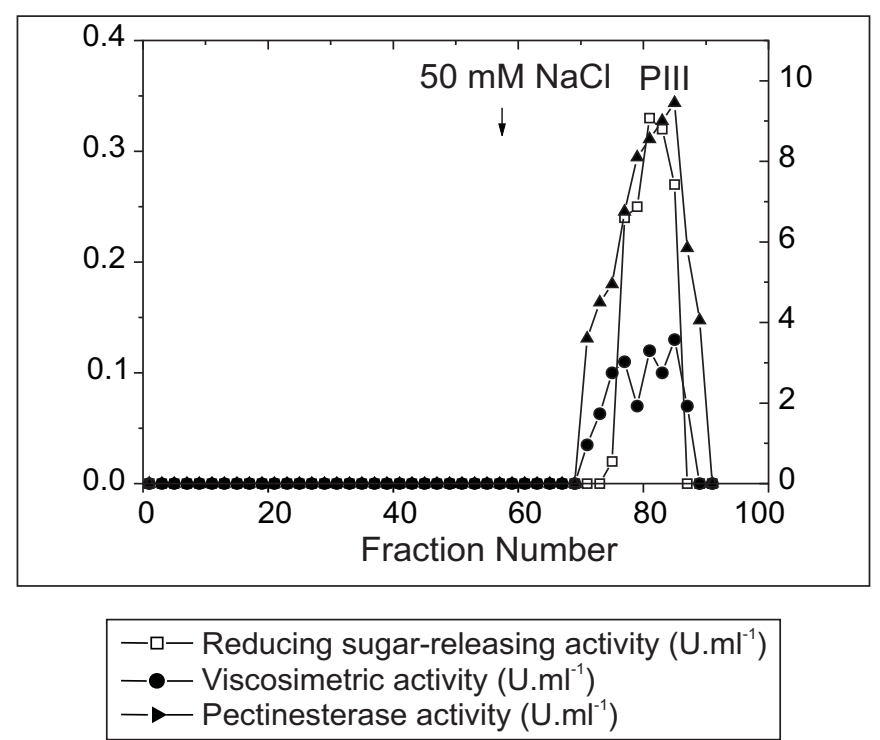
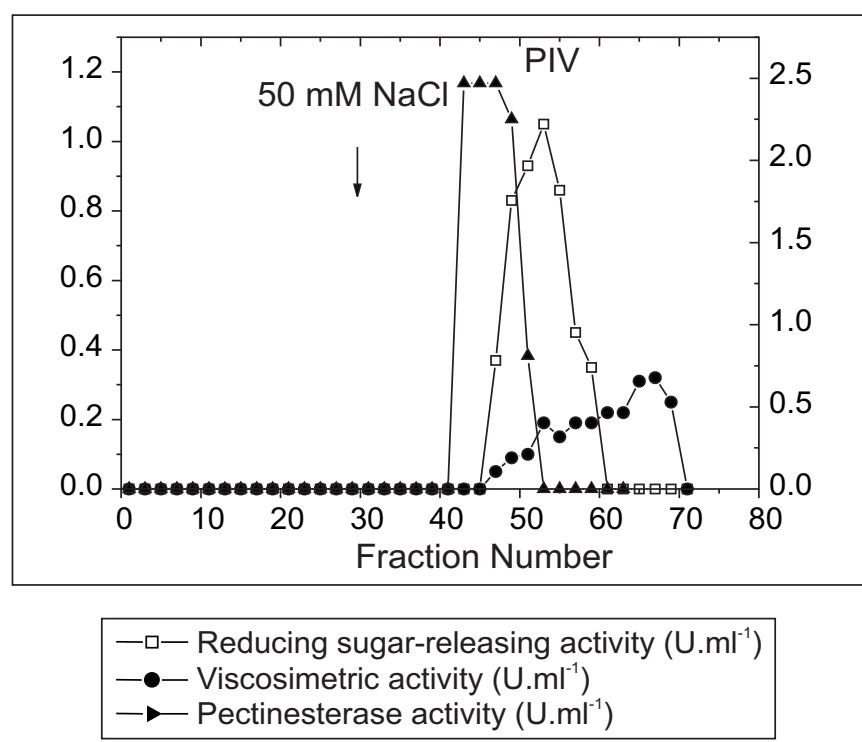

Figure 1. Separation profiles of the PIII and PIV fractions. The PIII and PIV fractions collected on a DEAE-Sephacel column (1.8 x $60 \mathrm{~cm}$ ) were rechromatographed under the same conditions and eluted with $50 \mathrm{mM} \mathrm{NaCl}$.

enzymatic degradation products, showing a high concentration of monogalacturonic acid when the viscosity of the NaPP solution was reduced by less than $50 \%$ (data not shown). So the polygalacturonases of the PIII and PIV fractions were named Exo-PG II and Exo-PG III. As also observed for Exo-PG I from $P$. frequentans (Chellegatti et al., personal communication), the sugar content of Exo-PG II and Exo-PG III indicated that they are also highly glycosylated (62.1 and $67.1 \%$, respectively). Most secreted fungal proteins are glycosylated by a process involving the binding of oligosaccharides to Asp, Ser and The residues on the surface of the protein molecule (16). Using concanavalin A and tunicamycin, Kawano et al. (10) elegantly showed the importance of the glycosylation process for the secretion of pectinases produced by $P$. frequentans. The molecular masses of Exo-PG II $(63 \mathrm{kDa})$ and Exo-PG III $(79 \mathrm{kDa})$, determined by gel filtration were similar to those reported for other fungal extracellular exopolygalacturonases, such as the $68 \mathrm{kDa}$ enzyme from Sclerotinia sclerotiorum (18), the $60 \mathrm{kDa}$ enzyme from Cochliobolus carbonum (21), the $78 \mathrm{kDa}$ enzyme from Aspergillus tubingensis (11), and the $74 \mathrm{kDa}$ enzyme from Fusarium oxysporum $\mathrm{f} . \mathrm{sp}$ (7). The fact that the molecular masses of Exo-PG I, Exo-PG II and Exo-PG III were higher than that of Endo-PG I produced by this fungus $(20 \mathrm{kDa})$ has been also observed in other fungi by Kester et al. (11), suggesting that this may be a general property of fungal exopolygalacturonases. The properties of Exo-PG II and Exo-PG III are summarized in Table 1.

The optimum $\mathrm{pH}$ and temperature determined for both enzymes did not differ greatly from those reported for other fungal exopolygalacturonases $(2,9)$. P. frequentans secretes 7 polygalacturonases, of which one endo-PG and one exo-PG have
Table 1. Physical parameters for Exo-PG II and Exo-PG III.

\begin{tabular}{lcc}
\hline \multicolumn{1}{c}{ Physical Parameters } & Exo-PG II & Exo-PG III \\
\hline $\mathrm{M}_{\mathrm{r}}($ Gel Filtration - Bio Gel P 100) & $63 \mathrm{kDa}$ & $79 \mathrm{kDa}$ \\
Optimum temperature & $50^{\circ} \mathrm{C}$ & $50^{\circ} \mathrm{C}$ \\
Optimum pH & 5.0 & 5.8 \\
$\mathrm{~K}_{\mathrm{m}}$ & $1.6 \mathrm{~g} / \mathrm{L}$ & $0.059 \mathrm{~g} / \mathrm{L}$ \\
$\mathrm{V}_{\text {máx }}$ & $2571 \mathrm{U} / \mathrm{mg}$ & $185 \mathrm{U} / \mathrm{mg}$ \\
\hline
\end{tabular}

been characterized (Chellegatti et al., personal communication). It may be questioned why a fungus synthesizes and secretes more than one enzyme for degrading a substrate in the same way. As shown in Table 1, P. frequentans Exo-PG II and Exo-PG III present differences in their biochemical properties which in turn are different from those observed for Exo-PG I (Chellegatti et al., personal communication). Scott-Craig et al. (21) suggested that the various exopolygalacturonase peaks observed for $C$. carbonum may be due to enzymes encoded by different genes and/or to post-translational modifications of a single gene product. Probably the synthesis of enzymes attacking a pectic substrate in the same way guarantees its degradation into monogalacturonic acid under a variety of environmental conditions, thus conferring an advantage to the microorganism that produces these enzymes.

\section{ACKNOWLEDGEMENTS}

This work was supported by grants from FAPESP ( ${ }^{\circ}$ 94/ 4760-7) and CNPq (PIBIC - USP/ 1998). 

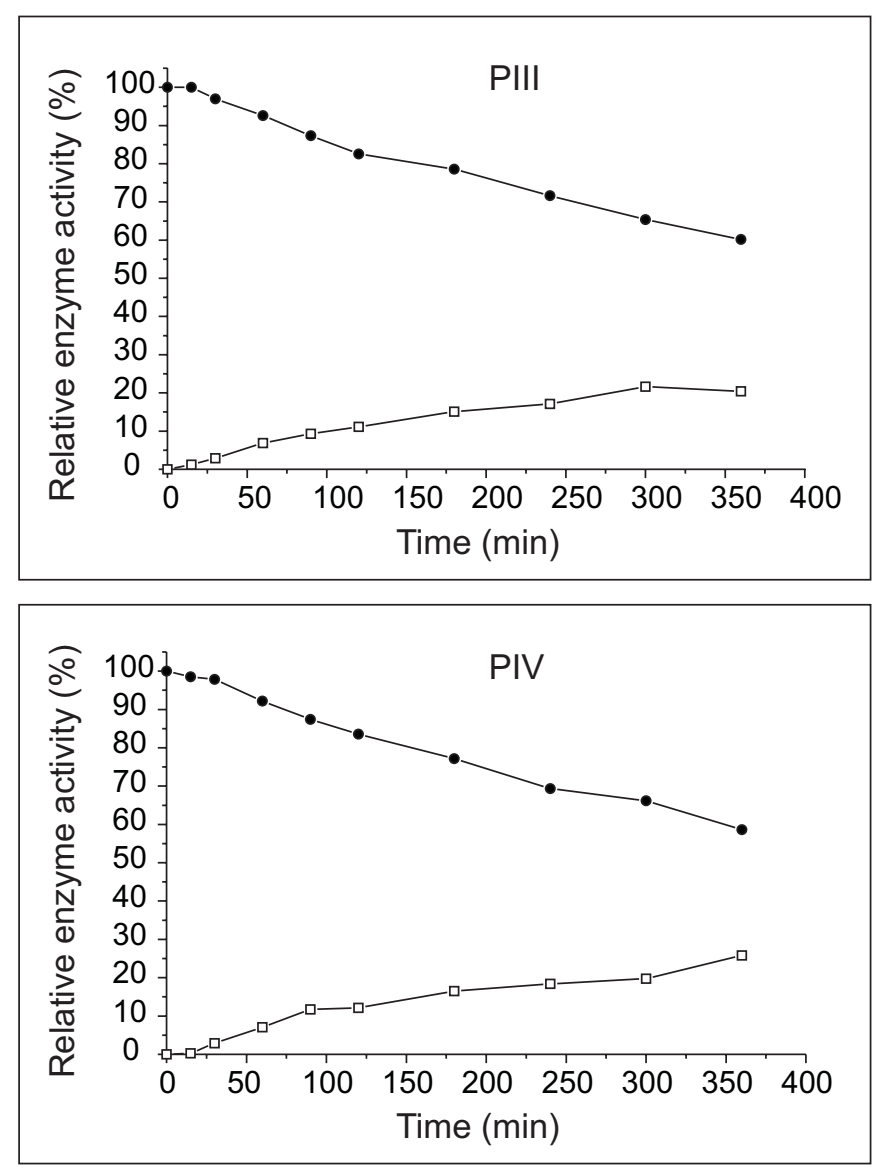

Figure 2. Determination of the exo-or endo-nature of PIII and PIV enzymes. The percentage drop in viscosity of $\operatorname{NaPP}(\bullet)$ was measured at different intervals with an Ostwald viscometer and simultaneous, the percentage of split glycoside bonds ( $\square$ ) was determined through the increase of reducing groups.

\section{RESUMO}

\section{Purificação parcial e caracterização das exopoligalacturonases II e III de Penicillium frequentans}

Estudos prévios realizados em nosso laboratório demonstraram que o fungo Penicillium frequentans produz altos níveis de poligalacturonase e pectinesterase. Endopoligalacturonase I (EndoPG I) e Exopoligalacturonase I (Exo-PG I) já foram previamente purificadas e caracterizadas. No presente trabalho foram separadas, purificadas parcialmente e caracterizadas bioquimicamente duas poligalacturonases extracelulares. Ambas foram caracterizadas como exopoligalacturonases e então foram designadas exopoligalacturonase II (Exo-PG II) e exopoligalacturonase III (ExoPG III) as quais apresentaram massa molecular de $63 \mathrm{kDa}$ (Exo-PG II) $79 \mathrm{kDa}$ (Exo-PG III). Os valores de Km foram 1,6e 0,059 g/Le os de $\mathrm{V}_{\text {maxx }}=2571$ e $185 \mathrm{U} / \mathrm{mg}$, respectivamente. A temperatura ótima de ambas foi $50^{\circ} \mathrm{C}$ e enquanto o $\mathrm{pH}$ ótimo da Exo-PG II foi 5,0 o da Exo-PGIII foi 5,8 .

Palavras-chave: Pectinase, exopoligalacturonase, poligalacturonase, Penicillium frequentans.

\section{REFERENCES}

1. Baracat, M.C.; Valentim, C.; Muchovej, J.J.; Silva, D.O. Selection of pectinolytic fungi for degumming of natural fibers. Biotechnol. Lett., 11: 899-902, 1989.

2. Behere, A.; Satyanarayan, V.; Padwal-Desai, S.R. Separation and limited characterization of three polygalacturonases of Aspergillus niger. Enzyme Microbiol. Technol., 15: 158-161, 1993.

3. Bensadoun, A.; Weinstein, D. Assay of proteins in the presence of interfering materials. Anal. Biochem., 70: 241-50, 1975.

4. Borin, M.F.; Said, S.; Fonseca, M.J.V. Purification and biochemical characterization of an extracellular endopolygalacturonase from Penicillium frequentans. J. Agric. Food Chem., 44: 1616-1620, 1996.

5. Call, H.P.; Walter, J.; Emeis, C.C. Maceration activity of an endopolygalacturonase from Candida macedoniensis. J. Food Biochem., 9: 325-348, 1985.

6. Cleveland, T.E.; Mc Cormick, S.P. Identification of pectinases produced in cotton bolls infected with Aspergillus flavus. Phytopathol., 77 (11), 1498-1503, 1987.

7. Di Pietro, A.; Roncero, M.I. Purification and characterization of an exo-polygalacturonase from the tomato vascular wilt pathogen Fusarium oxysporum f.sp. lycopersici. FEMS Microbiol. Lett. 1; 145 (2), 295-299, 1996.

8. Haidle, C.W.; Storck, R. Control of dimorphism in Mucor rouxii. J. Bacteriol. 92: 1236-1244, 1966.

9. Heinrichova, K.; Wojciechowicz, M.; Ziolecki, A. The pectinolytic enzyme of Selenomonas ruminantium. J. Appl. Bacteriol., 66: 169-174, 1989.

10. Kawano, C.Y.; Chellegatti, M.A.S.C.; Said, S.; Fonseca, M.J.V. Comparative study of intracellular and extracellular pectinases produced by Penicillium frequentans. Biotechnol. Appl. Biochem., 29: 133-140, 1999.

11. Kester, H.C.M.; Kusters-Van-Someren, M.A.; Müller, Y.; Visser, J. Primary structure and characterization of an exopolygalacturonase from Aspergillus tubingensis. Eur. J. Biochem., 240: 738-746, 1996.

12. Manachini, P.L.; Fortina, M.G.; Parini, C. Purification and properties of an endopolygalacturonase produced by Rhizopus stolonifer. Biotechnol. Lett., 9 (3): 219-224, 1987.

13. Mill, P.J.; Tuttobello, R. The pectic enzymes of Aspergillus niger. Biochem. J., 79: 57-64, 1961.

14. Miller, G.L. Use of dinitrosalicylic acid reagent for determination of reducing sugar. Anal. Chem., 31: 426-428, 1959.

15. Nasuno, S.; Starr, M.P. Polygalacturonase of Erwinia carotovora. J. Biol. Chem., 241: 5298-5306, 1966.

16. Peberdy, J.F. Protein secretion in filamentous fungi-trying to understand a highly productive black box. Trends Biotechnol., 12: 50-57, 1994.

17. Prade, R.A.; Zhan, D.; Ayoubi, P.; Mort, A.J. Pectins, pectinases and plant-microbe interactions. Biotech. Genet. Eng. Ver, 16: 361-391, 1999.

18. Riou, C.; Freyssinet, G.; Fevre, M. Purification and characterization of extracellular pectinolytic enzymes produced by Sclerotinia sclerotiorum. Appl. Environ. Microbiol., 58(2): 578-583, 1992.

19. Rombouts, F.M.; Pilnik, W. Pectic Enzymes. In: A.H. Rose, Ed. Economic Microbiology. Microbial Enzymes and Bioconversions. London, Academic Press. 1980, p-227-282.

20. Said, S.; Fonseca, M.J.V.; Siéssere, V. Pectinase production by Penicillium frequentans. World J. Microbiol. Biotechnol., 7: 607-608, 1991.

21. Scott-Craig, J.S.; Cheng, Y.Q.; Cervone, F.; de Lorenzo, G.; Pitkin, J.W.; Walton, J.D. Targeted Mutants of Cochliobolus carbonum Lacking the Two Major Extracellular Polygalacturonases. Appl. Environ. Microbiol., 64: 1497-1503, 1998.

22. Siéssere, V.; Fonseca, M.J.V.; Said, S. Extracellular polygalacturonases from Penicillium frequentans: separation and regulatory aspects. $J$. Gen. Microbiol., 138: 1801-1805, 1992. 